\title{
The Expansion of Mass Education in Botswana: Local and World Society Perspectives
}

JOHN W. MEYER, JOANE NAGEL; AND CONRAD W. SNYDER, JR.

Since the end of the Second World War, the growth of education is notable for several reasons. First, the institutions of mass education have spread to virtually all countries despite vast differences in political, economic, social, and cultural organization. Second, rates of enrollment around the world are high and represent enormous financial investments by many impoverished states and economies. ${ }^{1}$ And, third, the rapidity of educational expansion across states was unanticipated, its speed catching by surprise both theorists and practitioners alike.

Functional theories of the right or the left that stress national factors have conspicuously failed, since educational expansion has spanned state boundaries despite great variations in productive capacity and social mobilization. The functionalist view has generally been replaced by "conjuncturalist" or historicist arguments that local combinations and conflicts of interest and status groups produced expansion. ${ }^{2}$ However, historicism, with a focus on local factors, does not explain well a social change that is worldwide.

World-level processes seem to be at work. It has been argued that general models of modern society and the nation-state have spread rapidly, with mass education as a derived consequence of the urgency of national integration and development. ${ }^{3}$ Others have emphasized the tendency for modern education itself - and the associated model of the individual life course - to flow directly as ideology and practice around

${ }^{1}$ P. Coombs, The World Educational Crisis (Oxford: Oxford University Press, 1968); Unesco, Statistical Yearbooks (Geneva: United Nations, 1965-90); F. O. Ramirez and J. Boli, "Global Patterns of Educational Institutionalization," in Institutional Structure: Constituting State, Society, and the Individual, ed. G. Thomas, J. W. Meyer, F. O. Ramirez, and J. Boli (Beverly Hills, Calif.: Sage, 1987), pp. 150-72; J. W. Meyer, F. O. Ramirez, R. Rubinson, and J. Boli, "The World Educational Revolution, 1950-1970," Sociology of Education 50 (October 1977): 242-58; J. W. Meyer, F. O. Ramirez, and Y. N. Soysal, "World Expansion of Mass Education, 1870-1980," Sociology of Education 65 (1992): 128-49.

2 R. Collins, "Functional and Conflict Theories of Educational Stratification," American Sociological Review 36 (1971): 1002-19, "Some Comparative Principles of Educational Stratification," Harvard Educational Review 47 (1979): 1-27; M. Archer, Social Origins of Educational Systems (Beverly Hills, Calif.: Sage, 1979); see the review by J. Craig, "The Expansion of Education," Review of Research in Education 9 (1981): 151-210.

${ }^{3} \mathrm{~J}$. Boli, F. O. Ramirez, and J. W. Meyer, "Explaining the Origins and Expansion of Mass Education," Comparative Education Review 29 (1985): 145-70; Ramirez and Boli; G. Thomas, J. W. Meyer, F. O. Ramirez, and J. Boli, eds., Institutional Structure: Constituting State, Society, and the Individual (Beverly Hills, Calif.: Sage, 1987).

Comparative Education Review, vol. 37, no. 4.

(C) 1993 by the Comparative and International Education Society. All rights reserved.

$0010-4086 / 93 / 3704-0005 \$ 01.00$ 
the world. ${ }^{4}$ Empirically, the expansion of mass education across and within countries has the statistical characteristics captured by diffusion models. ${ }^{5}$ But diffusion is a descriptive model, not an explanation, and it is necessary to specify its mechanisms.

The organizational apparatus of the world centers that orchestrate the diffusion of mass education (e.g., the UN system, the World Bank, professional bodies, and national aid programs) has received some attention. ${ }^{6}$ For many reasons, these international actors all now embrace a global vision of rapidly developing independent states, and mass education is seen by all as a crucial property (and cause) of political and economic development. Most of this research has its focus on the center, examining core ideology, interests, and organization. However, much can be gained by looking at the matter from the other end, asking, Why have peripheral areas of the world been so quick to adopt cultural and institutional arrangements that touch so close to main values, as mass education does?

This article reports perspectives of mass educational expansion from the periphery through the example of a country that only recently embarked on this course - the Republic of Botswana, in southern Africa. Despite its peripheral character and relative newness among the world's states, Botswana has, to a surprising extent, rapidly implemented modern educational policies taken directly from metropolitan centers. We consider how both public and official perceptions in Botswana enrich our understanding of rapid educational expansion and modernization. This information was derived from interviews with Botswana educational professionals and consumers at both the local and national levels. We want to understand why, in Botswana, as around the world, education is unchallenged as both the remedy for the present and the recipe for the future.

\section{Background to Botswana's Educational Expansion}

Botswana is a large but sparsely populated (slightly more than 1 million in 1988) country on the arid inland plateau of southern Africa. ${ }^{7}$ In the twentieth century, the population, comprising mainly Tswana groups, has been dependent on cattle and dryland agriculture, with labor migration to the South African mines. Throughout the first 6 decades of this century, the main local political concern was less to achieve autonomy from colonial rule (Botswana was a protectorate rather than a colony) than

${ }^{4}$ K. Huefner, J. W. Meyer, and J. Naumann, "Comparative Education Policy Research: A World Society Perspective," in Comparative Policy Research: Learning from Experience, ed. M. Dierkes, H. N. Weiler, and A. B. Antal (London: Gower, 1987), pp. 188-243; C. McNeely, "Cultural Isomorphism among Nation States" (Ph.D. diss., Stanford University, 1989).

'Meyer, Ramirez, Rubinson, and Boli; Meyer, Ramirez, and Soysal.

6 Huefner, Meyer, and Naumann; McNeely.

${ }^{7}$ Unesco, 1989. 
to avoid absorption by South Africa or Rhodesia. ${ }^{8}$ Since independence in 1966, Botswana's democratic government has been engaged in a continuing national effort to avoid being overwhelmed by entanglements with neighbors involved in a series of dramatic internal conflicts (in Rhodesia/ Zimbabwe, South West Africa/Namibia, and South Africa, as well as Angola and Mozambique).

The current economy depends on a limited number of export commodities (principally recently developed diamonds, but also copper, nickel, and cattle) producing a GNP per capita of $\$ 880$ in 1988 , which is one of the highest in sub-Saharan Africa. ${ }^{9}$ The central government benefits directly from the revenues involved and is in a relatively strong financial position. Both revenue and governmental capacity are strengthened by a strong involvement in external assistance programs from many sources.

Traditional schooling in Botswana centered on training and discipline organized around initiation ceremonies, with nothing resembling modern schooling. Missionary schooling came early in the 1800 s, but on a very limited scale, and British investment was nominal. At independence, primary enrollments represented a very small percentage of school-aged population; there were 251 primary schools and nine secondary schools in the country. ${ }^{10}$ By 1985 the number of primary schools had doubled to 558 , and the number of secondary schools grew to $68 .{ }^{11}$ Since 1966 , educational expansion has been very rapid, representing nearly a fivefold increase, from fewer than 80,000 students in 1966 to more nearly 400,000 in 1990.

At present, primary education is nearly universal in Botswana, and in the 1980s it embarked on a program of universal 9-year (junior secondary) education. This required the creation of many new junior secondary schools: the number growing from just over 40 in 1983 to more than 120 in $1989 .{ }^{12}$ Senior high school education remains limited and selective, though there are discussions about its expansion. At independence there was no university, but (after the breakdown of a joint university with Lesotho and Swaziland) the University of Botswana was created in 1981.

Botswana represents a clear instance of the rapid expansion of mass education. The enrollments involved are by no means simply paper figures. There is a workable record-keeping and inspection system. The schools reported exist, operate for something like the required hours per

${ }^{8}$ F. Morton and J. Ramsay, The Birth of Botswana (Gaborone: Longman, 1987).

${ }^{9}$ Unesco, 1989.

${ }^{10}$ Republic of Botswana, National Development Plan, VI, 1985-1991 (Gaborone: Republic of Botswana, December 1985).

${ }^{11}$ Ministry of Education, Twenty Years of Education for Kagisano, the 1985/86 annual report of the Ministry of Education (Gaborone: Republic of Botswana, 1986).

${ }^{12}$ C. W. Snyder, Jr., and B. Fuller, "The Qualitative Context of Educational Change" (Gaborone: Junior Secondary Education Improvement Project, 1989). 
day and days per year, with substantial and reasonably paid teaching staffs (shortages produce demand for expatriate teachers coming from other African countries as well as from other continents), and so on. ${ }^{13}$ The quality of education remains a challenge. Teacher qualifications are low, students are often ill prepared, curricula and instructional materials are limited, and on comparative achievement tests Botswana scores are low, as is characteristic of Third World countries. ${ }^{14}$ But mass education is, in fact, in place.

These revolutionary changes toward mass education have gone on with little opposition and with less conflict than might have been expected. In the next sections, we discuss local perspectives that have attenuated potential opposition and provided positive support for the radically altered institutional system. We then consider some consequences of patterns of acceptance.

\section{Methods}

In describing Botswana perspectives on mass education, we rely on documents describing public policies, on historical materials, and especially on information on public orientations toward the modern educational system. In particular, we examine reports on three large local educational "Consultative Conferences" sponsored by the Ministry of Education and the United States Agency for International Development (USAID) in 1988 and $1989 .{ }^{15}$ The conferences were intended to get local input and responses on educational policies and issues (local consultation, in the form of an institution called the kgotla is a traditional as well as contemporary feature of Botswana). ${ }^{16}$

The conferences were structured around reports and small group discussions. These began with short videos depicting quite diverse and sometimes very critical views of government programs. Each conference involved 30-40 local (usually rather elite) participants, a dozen or so

${ }^{13}$ Educational Efficiency Clearinghouse, Botswana Education and Human Resources Sector Assessment Update (Tallahassee Learning Systems Institute, March 1986).

${ }^{14}$ A. Inkeles, "The International Evaluation of Education Achievement: A Review," Proceedings of the National Academy of Education 4 (1977): 139-200; S. Heyneman and W. Loxley, "The Effect of Primary School Quality on Academic Achievement in 29 High and Low-Income Countries," American Journal of Sociology 88 (1983): 1162-94.

${ }^{15}$ Ministry of Education, Therisana Ka Thuto: Community Consultation on Basic Education for Kagisano, National Curriculum Consultative Series Proceedings, ed. C. W. Snyder, Jr. (Gaborone: Department of Curriculum Development and Evaluation, May 1988), vol. 1; Ministry of Education, Therisana Ka Thuto: Community Consultation on Basic Education for Kagisano, National Curriculum Consultative Series Proceedings, ed. K. Noel (Gaborone: Department of Curriculum Development and Evaluation, October 1988), vol. 2; Ministry of Education, Therisana Ka Thuto: Community Consultation on Basic Education for Kagisano, National Curriculum Consultative Series Proceedings, ed. K. Noel (Gaborone: Department of Curriculum Development and Evaluation, July 1989), vol. 3; hereafter cited as Therisana Ka Thuto.

16 Morton and Ramsay. 
officials from the Ministry of Education, and a similar number of facilitators.

The results of the conferences were subsequently published. To aid in understanding these reports, interviews were conducted in June 1990, with local and ministry participants at one of the regional conference sites in Maun, a city in northwestern Botswana.

\section{The Local View}

Most striking about the Consultative Conference participant commentary, in both interviews and the conference reports, is the extent to which views rest on resolutely modern assumptions. ${ }^{17}$ While substantive issues were sometimes different from those that might concern a parent in, say, Wichita or Tallahassee, the tone of the discussion was neither critical nor ambivalent about the inevitability of the modernization of education.

In response to a question about whether Maun participants would have preferred education to be more locally adapted, a participant responded, "People here want the schools to be just like those in Gaborone [Botswana's capital] . . . they ask, 'why don't we have the same facilities?'" This is true despite the potential negative consequences of educational expansion in the absence of parallel economic expansion. Speaking of the unemployment of educated youth, the same person commented, "Soon it will be just the same here as in Gaborone. All the school leavers will be on the streets stealing. Nothing will be safe. We are educating them to be robbers."

Despite this troublesome observation, participants did not challenge the educational project. Modernity was taken for granted as a kind of natural fact, as simply a reality (as an objective value, in a sense), with costs recognized but inevitable. Several specific assumptions involved were notable in the discussions.

1. Botswana is to be seen as a national society. - Botswana is not a collection of tribes, of ancestral polities, of corporate familial groups, or of traditions. "Society" has the standard modern sociological meaning: a social system in the conventional sense, made up of rationalized interdependent components and organized in such subsystems as the economy and political system. The basic entities in this vision are individuals holding occupational roles in the formal sector. And the discussions universally assume that young people will either have occupations in this sector or be "unemployed."

This vision of Botswana is surprising, since it defines the traditional work life patterns of most of the population as "unemployment." Since

\footnotetext{
${ }^{17}$ For example, as discussed by A. Inkeles and D. A. Smith, Becoming Modern (Cambridge, Mass.: Harvard University Press, 1974).
} 
the past patterns of rural youthful village life no longer have meaning, the realistic, limited work future of a great many young people is perceived as a "social problem" calling for (prominently educational) action. Thus the entire traditional work system is no longer seen as culture (to be analyzed by anthropologists) but is reconceived as economic and social pathology. The interviews and conference discussions are filled with concern about this social problem as well as with educational approaches to its solution.

2. Botswana is made up of individuals. - A life course meaningful for them at the individual level must be found. This is a matter, not only of social order, but of individual justice as well. It is assumed that the life course should be integrated, for example, so that early socialization and education flow smoothly into a later occupational career. This emphasis on the individual entirely leaves out any traditional notion of the submission of the individual to life stages organized around collectives (e.g., tribes, extended families, and the like). Life course discontinuities that might have been perfectly sensible in a traditional scheme (e.g., long periods of passive and unpaid conformity) are now social problems - both unjust in the new perspective of the "individual" and inefficient to the new "society."

In this view, the collective good derives from the development of individual life courses, a perspective that is at the root of much educational expansion and reform. ${ }^{18}$ The view is very strong in Botswana and contrasts there with a cultural tradition emphasizing the importance of obedience to an authority derived from communal society. Illustrative of the modern emphasis on the individual is the fact that even those conference discussions emphasizing the importance of education in cultural matters employed the language of child development: "We need to develop the child ... to maintain values, ethics, and manners." 19

3. Education is to replace the family and more traditional socializing institutions. - The lives of young people should be managed by an educational system, which will be universal, standardized across Botswana, modern in content, and extended in years. Preparation needed for any aspect of life (from work to politics, from family roles to ethnic culture) is defined as the proper province of the educational system. Traditional familial and communal socialization (just like traditional work patterns) are relegated to the dustbin of "culture" and seen as authoritarian and even abusive in modern terms.

By way of explanation for this abdication of traditional authority to the schools, conference participants make the standard remarks about

${ }^{18}$ R. Fiala and A. G. Lanford, "Educational Ideology and the World Educational Revolution," Comparative Education Review 31 (1987): 315-33.

${ }^{19}$ Therisana Ka Thuto, 2:95. 
the failures of parents and other community components properly to socialize the young. But the main assumption is that the schools will now do the job. This is no more plausible in Botswana than elsewhere, but it opens the door to an enormous amount of educational expansion and modernization. Ironically, schools are expected to provide solutions to public fears about the loss of cultural tradition even as they undermine it. So, the schools are assigned the task of including culture and tradition in the national curricula and teacher training programs: "[The curriculum] should incorporate traditions, language, cultural diversity, history, and Tswana values. We need to develop professionals responsible for the following areas: continuous consultation with elders to maintain components of culture and expertise in history, anthropology, social studies, art, and music." 20

Besides the maintenance of tradition, the schools are mandated to solve new social problems. For instance, teenage pregnancy, common in traditional village life, reconceptualized as a problem in the modern order, resulted in a call by conference participants for "Family Life Education, home management, community and personal health as part of the general curriculum." 21

4. Botswana is to be seen as a nation-state.-Its society, life courses, and socialization are to be nationwide and the responsibilities of the national state. Botswana is not to be seen as a collection of disparate groups but as an integrated entity whose policies are to be formulated nationally. Deviations from this are not seen as desirable instances of localism but as exceptions and failures to be overcome. This vision appears even in Maun, a far northern region with a rich, somewhat independent tradition and a distinct ecology and economy:

No, we don't want anything different here [in Maun]. We just want it to be the same as they have elsewhere. This area is far from Gabarone, and has been a backward area. People here want to catch up to the south. ${ }^{22}$

I'm an advocate of a little more decentralization, but simply because it's more efficient, not to create a special educational program here in Maun. Policy should be centrally set. ${ }^{23}$

Beyond the expectation that education should be effectively standardized, there is the pervasive assumption that it can be controlled centrally. It is assumed that the Ministry of Education can maintain direct organizational links with dozens of other bodies from local communities to other national ministries. Central responsibility is stressed:

${ }^{20}$ Ibid., pp. 94-5.

${ }^{21}$ Ibid., vol. 3, session 2, group 1, p. 2.

22 Interview with a Maun parent.

${ }^{23}$ Interview with a Maun business administrator. 
Educational administrators at the Ministry level hold a key function by ensuring that basic education is provided for all and that the practical components of the curriculum ... are given appropriate emphasis. ${ }^{24}$

Ministry of Education must get input from various bodies to bring about desired changes,... Affected groups generally do nothing since they are looking up to the Ministry of Education for direction. ${ }^{25}$

By this logic, even the democratic process must be carried out centrally, despite a long Botswana tradition of local decision making: "The Ministry of Education should have frequent consultations regarding curriculum design and content with as many stakeholder groups as possible." 26

\section{Impact of the Local View}

The four assumptions discussed above create a world with two properties highly important to our discussion: (1) public and official openness to a centralized educational system as the route to social efficiency and the equality of educational opportunity and (2) public and official demand for rapid educational expansion as the solution to social problems.

\section{Openness to Centralized Educational Planning and Administration}

In Botswana, the local world is organizationally open to central (indeed, international) policy and authority: it is eager for the higher, centrally established truths. Over and over, there were active pleas for communication from and connection to the center. This was especially striking in a system that is changing rapidly and in which very progressive ideals are in some contrast with practical realities. ${ }^{27}$ Such orientations can explain why there was little local resistance to a recent central takeover of long-standing community-established and community-run junior secondary schools.

The local commitment to the new national junior secondary ("Nine Year") program is all the more notable given the lack of clarity surrounding it:

What needs to be communicated? ... What is the new system? ... What are the advantages over the old system?... What are the practical implications of this change?... Who is eligible?28

[We need] information on the Nine Year Programme, BUT presented in a form that can be easily understood by parents and community workers. ${ }^{29}$

${ }^{24}$ Therisana Ka Thuto, 1:80.

${ }^{25}$ Ibid., vol. 3, session 3, group 1, p. 1.

26 Ibid., 2:100.

${ }^{27} \mathrm{~J}$. W. Meyer and B. Rowan, "Institutionalized Organizations," American Journal of Sociology 83 (September 1977): 340-63, and "The Structure of Educational Organizations," in Environments and Organizations, ed. M. W. Meyer (San Francisco: Jossey-Bass, 1978), pp. 78-109.

${ }^{28}$ Therisana Ka Thuto, 1:58-59.

${ }^{29}$ Ibid., p. 60. 
Communities (parents) know nothing.... Community leaders have not been informed. The result is they convey inadequate information.... Teachers do not seem to have been informed. ${ }^{30}$

People are still confused about when is the Nine Year Programme. Is it now? When will it be universal? A lot of people are begging for places. When is it going to start?

Even our syllabus is still an interim one. The Primary syllabus is unclear: When are people supposed to start teaching it? I work with ... teachers, and you're not clear when they're supposed to start teaching the new syllabus. There's an old, an interim, and a new syllabus.... Several years ago they were changing the syllabus several times in a year. ... If you missed that particular mailing, your kids were out of luck. ${ }^{32}$

These discussions are filled with criticisms of the educational system. But the call is not for the adaptation of local education to local reality. It is for better transmission of national policies to the local area. Thus, informed people in one of the most peripheral areas of a quite peripheral country are educational cosmopolitans, not locals. They are organizationally available for centrally directed change.

\section{Demand for Rapid Educational Expansion}

The four assumptions of modernity discussed above generate not only a procedural inclination to look to central national models and directions but also a substantive commitment to rapid educational expansion and modernization. The assumption that education should be the main socializing instrument of society turns every social goal and problem into a rationale for improving education and along the most modern lines. Thus, in the Consultative Conference discussions, problems ranging from unemployment to crime to family disorganization and illegitimacy generated calls for educational solutions, often paralleling those found in developed societies.

The assumption that society is made up of individual life courses similarly turns life discontinuities into problems ripe for educational solutions. Education must be expanded to prepare young people better for individual careers (and, thus, the older, more elitist selective educational arrangements disappear with little resistance). Curricula must become relevant to a wide range of occupational prospects (and, thus, the traditional British curriculum also rapidly disappears). Elaborate guidance arrangements are proposed-in a country with no psychological tradition, whose university has no psychology program-to link

${ }^{30}$ Ibid., vol. 3, session 3, group 1, pp. 1-2.

31 Interview with a Maun educator, June 1990.

32 Interview with a Maun educator, June 1990. 
students better to worlds of work and family life (and, thus, the capacity of traditional institutions of village and kin to prepare children for adult life give way to the school). The assumption that Botswana is a society of individuals with occupations-dramatically unrealistic in practice, given the limited modern sector of the economy-produces an enormous range of solutions calling for educational modernization. Curricular and guidance changes are proposed. And in the face of the unrealism involved, there are suggestions to train students to create their own jobs (entrepreneurially), as well as for the educational system itself to engage in job creation schemes.

Practically speaking, every educational solution found in developed countries, dealing with the widest range of social problems, is welcome in local Botswana perspectives. One does not need to postulate international or national coercion to explain local educational expansion and modernization in Botswana.

\section{The National Policy View}

National elites have not forced educational change on an unwilling Botswana-many decisions have been driven by societal demands. Local and national elites have generally taken parallel positions, undergirded by the shared assumptions discussed above. In the official view, there is the same perception of society in modern terms, prominently emphasizing an economic system made up of individuals with occupations, but also including other dimensions of individual life (e.g., family, politics, and so on). While there are certainly controversies in Botswana, they are not centered on education. For instance, a 1984 review of education for development in Botswana, incorporating the most diverse and conflicting views on models of economy and society, shows only the most modest conflicts about educational policy ideals. ${ }^{33}$ Such sparks as occur in this review focus on failures of implementation, putative ineffectiveness, or the inability of educational change to affect social and economic inequalities and inertial forces. Nowhere are questioned the fundamental assumptions about the wisdom of educational expansion.

Even before independence, local political elites had emphasized the value of education in a general way. With independence, education was advanced as essential for national development. The major step in this direction was the appointment of a National Commission on Education in 1976. This commission's report, and an ensuing government white paper that laid the basis for all subsequent policy developments, were

${ }^{33}$ M. Crowder, Education for Development in Botsuana (Gaborone: Macmillan, 1984). 
adopted as national policy in 1977 and are still cited frequently by educational policymakers and others. ${ }^{34}$

The 1977 report moves sharply away from a Botswana educational tradition (initially mainly religious and later British and secular) that emphasized elite education in a diffuse way. The 1977 vision directly parallels the prevalent local assumptions discussed above and embraces widespread individual participation in all aspects of modern life. It takes for granted that Botswana is to develop in modern ways and defines education as a crucial factor in development. No positive alternative is considered. The only alternative is national failure.

The 1977 report also takes for granted that the functions of education operate entirely by socializing individuals for their roles in society. There is no sense that education should in any way sacrifice individual persons for the maintenance of the culture or tradition. Education in the traditional culture is advocated, because it will benefit individuals by helping them make sense of their lives.

The adoption of the 1977 report led to much educational expansion and change. The drives for national standardization, for universalization, for extension beyond primary school, and for curricular modernization, were set in motion in the vision of society the report contained. Subsequent national development plans have incorporated the same ideas whole - and in each case furthered the expansion of education, with the same justifications. ${ }^{35}$

The breadth of educational goals are shown in Appendix A, which provides two different but related lists of the aims of Botswana's basic education program. Both lists are in circulation at the national level, and both have semiofficial status in national discussions. Either list would legitimate the most modern and expanded educational system to be found anywhere in the world. Both lists were constructed by expatriate educational technical staff; neither list was significantly altered prior to wide national adoption.

\section{Impact of the National View}

\section{Educational Expansion}

The emphasis on education as a crucial ingredient of every aspect of public life, and the emphasis on the national character of society, make the omission of various social groups a conspicuous social problem. Insofar as the educational system is slow to reach distant or sparsely settled areas,

${ }^{34}$ Republic of Botswana, Education for Kagisano, report of the National Commission on Education (Gaborone: Republic of Botswana, 1977); Republic of Botswana, National Policy on Education: Government White Paper no. 1 (Gaborone: Republic of Botswana, 1977).

${ }^{35}$ For example, Republic of Botswana, National Development Plan (n. 10 above). 
an important regional injustice exists, one that is addressed by setting in place boarding arrangements. To the degree the Bushmen-traditionally deeply subordinated by dominant Tswana groups-are excluded, or are less eager for schooling, an ethnic injustice exists, one addressed by theories of their mistreatment and proposals for repair.

The same pressures expand secondary education. Interestingly, in Botswana, local groups created secondary schools, and then pressure arose for national incorporation and support. Soon, however, access to secondary schools became unevenly distributed, constituting a serious social problem. Currently, a remedy applied to the youth unemployment problem is to keep students in school. Thus, senior secondary enrollments are expanding. Another solution is for more special curricula, including the development of vocational training.

\section{Curricular Modermization}

The expanded vision of the role of education embodied in the national view involves a greatly elaborated and modernized curriculum. The older restricted forms of knowledge characteristic of British traditions are overwhelmed in multidimensional liberalization. With all the legitimated new motives for educational change, many new claimants can demand entry.

This has generated radical curricular change, especially in basic education. History and geography are gone, replaced by social studies instruction that starts with the child in family and village, working up slowly over the years to region and country, then to southern Africa and Africa overall, and finally the world. The world, in this curriculum, consists mainly of the UN system and its rules (including notions of human rights that have special significance for southern Africa). Little attention is given to such parts of this world as the Americas or Europe, though the student learns the names of mainly European Economic Community countries that purchase Botswana's exported beef.

The stress is on the child as a participatory individual at the center of this great enterprise, not on history from the enterprise's point of view. Other subjects are similarly modernized, and new subjects added reflect a broader curriculum (art, design and technology, environmental education).

\section{Changed Services}

Beyond expansion and curricular change, there are continuing efforts-fueled in part by the 1977 National Commission Report-to change the relation of the child to the schooling system. Prominent here is the expansion of guidance and counseling services-alien to traditional ways of thinking but required in the new order.

Similarly, changed patterns of instruction and discipline are promulgated. Botswana tradition emphasizes physical discipline, and beatings 
were a principled part of both traditional and early Western instruction. Corporal punishment was used not only to deal with what moderns call "deviant behavior" but also to punish insufficient performance. By rule, though less in practice, this is increasingly restricted. Similarly, more traditional instructional forms (lecture, recitation, and so on) are discouraged, though still dominant in practice, ${ }^{36}$ and new child-centered pedagogical methods are advocated. To such ends, teacher training with much more emphasis on the educational process (as opposed to the traditional British concern with substance) is increasingly emphasized, along with an extensive system of in-service training.

\section{The International Level}

Educational change in Botswana is best understood in terms of worldwide understandings about education, modernity, the individual, and the nation-state. It is easy to argue that local orientations and national policies are penetrated by such wider ideational and institutional forces. In this case, we can go much further, arguing for specific organizational connections between Botswana and the dominant educational frames of world society. Historically, Botswana has had close relations with supportive international bodies, many of which have provided educational funding and personnel. The recency and rapidity of development have meant that the supply of citizens prepared for emergent system roles has been limited. As a result, both programs and personnel have been imported. Appendix B provides a list of some of the external programs involved in Botswana education during the period from 1973 to the present and indicates the types of support they have provided.

As the Appendix indicates, international involvement in Botswana's educational system is widespread and pervasive, involving many American, European, and international agencies, including the United States Agency for International Development (USAID), the British Overseas Development Agency (ODA), the Australian International Development Assistance Bureau, the World Bank (IBRD), and the United Nations. The activities of these agencies have been quite diverse, notably:

1. The 1977 National Commission on Education, which has had such an impact on subsequent development, was chaired by Torsten Husen, the renowned Swedish educator.

2. The revised and expanded curricula associated with educational modernization have been developed with substantial support from USAID. Materials development has relied heavily on expatriates often funded by USAID as well as the ODA.

${ }^{36}$ B. Fuller and C. W. Snyder, "Vocal Teachers, Silent Pupils?" Comparative Education Review 35 (1991): 274-94. 
3. Similarly, changes in teaching methods, and the creation of inservice programs and teacher training programs, have been funded by USAID and ODA.

4. Guidance and counseling programs are expanding with heavy external involvement. Models come from the developed world and focus on current, highly psychologized emphases rather than more traditional career counseling.

5. Finally, we note again that the two commonly cited lists of the aims of the national mass educational system contained in Appendix A were both prepared entirely by expatriates operating on external funding.

A more systematic way to examine the impact of external funding and staffing can be seen in Appendix C. The Appendix identifies the major organizational components of the Ministry of Education, and shows that all of these units were created or supported by international agencies during the period since the early 1970s.

In many analyses, this pervasive external influence would be described as domination or hegemony. Such conceptions, invoking an image of power relationships, do not provide the most useful model of what happens in Botswana. It is not obvious that the interests of donor agencies gain or that Botswana interests lose in the transactions involved. Botswana local and national constituencies seek the institutionalization of a model of education and society analogous to that obtaining in the core, as well as external resources to provide the technology to produce this model. The local Consultative Conferences show that participants are highly involved in the pursuit of progress as measured, not by local, but by world standards. National elites work in a consistent manner. The picking and choosing from themes of modern world educational discourse are a continuing and active process.

If hegemony is involved, it is at a much more general level in rationalistic principles of society and state, and in the meaning of individual citizenship. Once Botswana is envisioned as a society made up of individuals who are entitled and socializable citizens, with a national economic system that can be developed, lines of modernizing educational action follow.

Looking at the motivating considerations from the point of view of the metropolitan centers, we again find little resembling rawer material power. The educational ideologies put forward to the developing world bind together metropolitan educational systems as well. They are packaged as general truths applicable in all worlds, not as particularistic strategies for the Third World. ${ }^{37}$ It is not surprising, then, that they flow as truths to any society conceiving itself as modern.

${ }^{37}$ Fiala and Lanford (n. 18 above); Meyer, Ramirez, and Soysal (n. 5 above). 


\section{Some Consequences of the External Structuring of Education}

The external definition and organization of education has had several consequences for Botswana. Some of these are specific to Botswana; some are shared by educational systems worldwide.

First, modern educational policies appear quickly in Botswana and are absorbed rapidly. Partly this is because there is little tradition to block the adoption of new themes (the British system had a weak presence, and local traditions offer little competition in so peripheral an area). Further, entrenched interest groups are only weakly present, and their relative absence permits a more smooth flow of high modernity. ${ }^{38}$ Thus, primary school history and geography gave way more easily to the new social studies subject area in Botswana than in most European societies. ${ }^{39}$

Second, the exogenous origins of much educational change produce a great deal of organizational decoupling. ${ }^{40}$ This is less a matter of inconsistency between policy and (often nonexistent) prior practice than a matter of inconsistencies between $(a)$ rapidly changing policy and uncontrolled practice and $(b)$ policies and programs deriving from different exogenous origins. Thus, in Botswana world emphases on decentralization have produced multiple and uncoordinated sets of regional educational centers, new curricula have been developed which do not match established examining practices, and British models of educational administration (such as inspection) coreside and compete with much more liberal American models of complex organization. ${ }^{41}$

Third, educational reform in Botswana has an unexpectedly liberal character. In this democratic market society, American models tend to predominate, despite the absence of historical American links, the presence of traditional British (often via South Africa) connections, and a cultural orientation toward stability and authority. American-style programs of counseling, curriculum development, and highly child-centered instruction (and teacher training) have tended to win out.

Finally, the external character of much educational ideology and practice often means that very modern and liberal educational structures take

${ }^{38} \mathrm{~J}$. Holm, "How Effective Are Interest Groups in Representing Their Members?" in Democracy in Botswana, ed. J. Holm and P. Molutsi (Gaborone: Macmillan, 1989), pp. 49-67.

${ }^{39}$ S. Wong, "The Evolution of Social Science Instruction, 1900-1986," Sociology of Education 64 (1991): 33-47.

${ }_{40} \mathrm{~J}$. March and J. P. Olsen, Ambiguity and Choice in Organizations (Bergen: Universitetsforlaget, 1976); Meyer and Rowan, "The Structure of Educational Organizations" (n. 27 above).

${ }^{41}$ For further examples, see J. W. Meyer and J. Nagel, "Policy and Organization in Curriculum Development in Botswana," in Improving Instructional Quality, ed. C. W. Snyder, Jr., and P. T. Ramatsui (Gaborone: Macmillan, 1993), pp. 185-204; for Liberian examples, see J. Nagel and C. W. Snyder, Jr., "External Agendas and Internal Adaptations: The International Funding of Educational Development - the Case of Liberia," Comparative Education Review 33 (February 1989): 3-26; and C. W. Snyder and J. Nagel, "Institutionalizing Educational Development," in Advances in Educational Productivity, ed. D. W. Chapman and H. J. Walberg (Greenwich, Conn.: JAI, 1992), pp. 123-50. 
on in practice a "traditional" character. At the classroom level, it is clear to teachers, students, and parents that educational truths are defined at a vastly higher level than the local one, and they are valuable for precisely this reason. The great urgency of development and the great contrast between the educational "city on the hill" and local reality make the student and local community's experience seem of little value. Everything of value, such as student life chances, depends on national exams and world standards. In this respect, it is surprising that classroom teaching and work styles are almost unrelievedly traditional in that they are organized around mechanical learning and copying, around lectures and very restricted recitation questions. Discussion is very rare, as is any sort of explanatory or reflective inquiry. ${ }^{42}$

Both local people and outsiders tend to explain this with reference to Tswana culture, in which authority and discipline are emphasized. It may be as useful to see traditionalism as reinforced by the central and exogenous character of the value of education, which takes on ritual properties. ${ }^{43}$ It is thus plausible that passivity in the classroom is due more to the relationship of peripheral countries to modern education than to the inherent nature of traditional culture.

A similar condition holds in the relation between the classroom and the wider educational system. By all accounts, the curriculum (and policies about methods) are in principle to be established centrally. This new traditionalism shows up strongly in the Consultative Conference reports. There is much complaint about organizational and communication linkages, but little about lack of local autonomy.

The Botswana center also relies on the legitimacy and capacity of external stimuli. There is an inclination to wait until external sources generate solutions to problems. In creating the national curriculum, for instance, local processes tended to play a very passive role, using the ideas and products of outsiders (publishers, consultants, and external projects). The same has tended to be true of the other elements of the national educational system, as Appendix $\mathrm{C}$ shows. Thus the same high external value, or reification, of education that has helped generate rapid expansion and modernization has also tended to reinforce much passivity at every level of the system, from the student to the national ministry. This might not have been expected from the emancipatory character of the educational culture involved. In Botswana, it is very easy for an observer to subscribe to the criticisms of education put forward on this dimen-

${ }^{42}$ R. B. Prophet and P. M. Rowell, "The Curriculum Observed," in Curriculum in the Classroom, ed. C. W. Snyder, Jr., and P. T. Ramatsui (Gaborone: Macmillan, 1992), pp. 1-48. C. W. Snyder, Jr., and P. T. Ramatsui, eds., Curriculum in the Classroom (Gaborone: Macmillan, 1992).

${ }^{4}$ Meyer and Rowan, "Institutionalized Organizations" (n. 27 above), and "The Structure of Educational Organizations." 
sion-from Neill to Goodman to Illich and Freire. Such observers have always been sensitive to the inconsistency between the individual-centered content of modern educational ideology and the scientific and bureaucratic universalism that imposes this ideology on children-an inconsistency built into the phrase "compulsory education."

From one point of view, the effect on persons and structures in Botswana itself can be seen as the creation of "learned helplessness"- the principle that nothing one does matters and that external forces and events determine every outcome. ${ }^{44}$ This is the view embodied in the thinking of the earlier educational critics of the passivity created in many Third World educational systems in the face of the dominance of Western cultural themes. Such passivity may, for instance, produce personal and organizational ineffectiveness. We note, however, that the Western education model is a cultural system that emphasizes individual development and self-enhancement, themes that may permit an effective interpretation and response for both individuals and social systems confronting core ideologies and institutions. From another point of view-and one certainly held in Botswana-the external forces shaping educational change are acting for the benefit of the country. They are agents of its interests. In this case, one might think of "passivity as strategy" rather than inefficaciousness or learned helplessness. That is, by going along, indeed merging oneself, with virtuous processes going on in the wider world, one acquires and incorporates oneself with their powers.

Passivity in relation to world agents of high modernity is not unreasonable from a Botswana point of view. Historically, the groups comprising the modern population were mostly pushed there by more powerful groups, in various Zulu, Ndebele, Boer, German, and settler expansions. This discouraged a strategy of more active resistance, since every neighbor has been stronger. Historically, a link to the British Empire was a source of strength, not weakness. In the postindependence period, world markets for diamonds, copper, and nickel have greatly benefited the country, permitting escape from the constraints of a weak economy. Also during this period, the world principle of the sovereignty of the nation-state, upheld by the great world centers (i.e., the dominant powers, but also the organizations of the UN system) has been a main bulwark of national autonomy. And throughout Botswana history, cultural emissaries of the wider system, from missionaries to contemporary assistance programs, have been continuing sources of clear benefits. There is little reason to resist. If modernity is a cargo cult in Botswana, it is a very successful one.

${ }^{44}$ M. E. P. Seligman, Helplessness: On Depression, Development, and Death (San Francisco: W. H. Freeman, 1975). 
Finally, it has been common to note the culturally destructive effects of dominating Western culture in such institutions as education in Third World countries. ${ }^{45}$ We note here that in our data conflicts seem to occur less through direct opposition and resistance than through the replacement of traditional frames by modern ones, built around imagery about the nation-state, "society," and the individual. Individuals and organizations may thus experience less anomie and inconsistency than some extreme arguments would have it. What is occurring may be more the simple construction of new and standardized modern roles. Indeed, there are few data demonstrating anomic responses to the penetration of core educational cultures; rather, the negative outcomes stem from the slower modernization of other social sectors (especially the economy and polity). ${ }^{46}$

\section{Concluding Comments}

The adoption of world-legitimated notions of society, state, and individual citizenship has made educational expansion and modernization an important goal in Botswana-to local people as well as national elites. International structures have provided conduits to educational change, but not in the form of dominating centers. Rather, the resources, personnel, and models of education are sought and used in Botswana in the service of common assumptions about the importance of education.

The smooth character of the flows involved and the rapidity of educational change in Botswana have much in common with other developing systems. But some special features of Botswana have facilitated both the absence of resistance and the rapidity and actual implementation of changes. Favorable mineral discoveries provide much economic support for that national state and society. A threatened geopolitical location encourages external help. A relatively benign, and sometimes crucially protective, history as a British protectorate, gave legitimacy to çentral institutions and culture. Internal history - generating a very weak traditional economy-did little to develop strong intermediary groups that could have provided more resistance to modernization. Such factors have undoubtedly made the flow of modern educational elements to an extremely peripheral society more rapid and have weakened possible centers of resistance.

\section{Appendix A}

\section{Two Lists of Aims for Botswana Education through Primary and} Junior Secondary Levels

\section{Aims of the Botswana 9-Year Education Program}

1. Botswana language and culture.-Show knowledge and understanding of Tswana culture, language, literature, arts, crafts, and traditions.

\footnotetext{
${ }^{45}$ See, e.g., M. Carnoy, Education as Cultural Imperialism (New York: McKay, 1974).

${ }^{46}$ See P. Coombs, The World Crisis in Education: The View from the Eighties (New York: Oxford University Press, 1985).
} 
2. Botswana political, economic, and social life.-Realize the effect of Botswana's location in the African continent on political, economic, and social life in Botswana.

3. Botswana climate and ecology. - Appreciate climatic and ecological conditions prevalent in Botswana.

4. English language. - Understand English and use it appropriately, both as a medium of learning at school and as a vehicle of communication beyond school.

5. Home and financial management.-Apply knowledge and imagination to identify problems in household management and everyday commercial transactions, and have the mastery of basic scientific and mathematical concepts to resolve them. Know how to run a home and care for a family.

6. Self-sufficiency and rural development.-Acquire skills in food production and industrial arts for self-reliance, self-sufficiency, and rural development.

7. Observation and reasoning.-Be able to observe and record accurately and draw reasoned conclusions.

8. Basic skills for later studies and out-of-school occupations. - Effectively use commonly needed tools and instruments in activities connected with later studies and out-of-school occupations.

9. Self-assessment.-Be able to assess their own achievements and capabilities in pursuit of appropriate employment and/or further education.

10. Moral development.- Have developed a sound moral code of behavior compatible with the ethics and traditions of Botswana.

11. Adaptability to change.-Be able to adapt to social, economic, and technical change by adjusting acquired knowledge to new situations and by taking appropriate action.

Expanded Aims of the Botswana 9-Year Education Program

1. To gain knowledge and understanding of Tswana culture, language, arts, crafts, and traditions.

2. To understand and fulfill political, economic, and social obligations in the local community.

3. To understand and fulfill political, economic, and social obligations in the nation.

4. To understand and fulfill political, economic, and social obligations in Africa and the world.

5. To understand English and use it appropriately, as a medium of continued education and as a vehicle of communications in the community.

6. To apply knowledge and imagination to avoid or ameliorate problems in household management.

7. To apply knowledge and imagination in carrying out everyday commercial transactions in order to purchase and use goods and services wisely.

8. To understand the methods of science and mathematics and their influence on human life in everyday activities.

9. To acquire skills in food production for self-reliance and self-sufficiency.

10. To acquire skills in industrial arts for self-reliance and self-sufficiency.

11. To be able to think rationally and logically.

12. To be able to express thoughts clearly, and to read and listen with understanding. 
13. To appreciate the climatic and ecological conditions prevalent in Botswana.

14. To effectively use skills and instruments in activities connected with later studies or out-of-school work.

15. To gain the understanding and attitudes of successful workers.

16. To be able to assess personal achievements and capabilities realistically in pursuit of appropriate employment and/or further education.

17. To develop a sound moral code of behavior compatible with the ethics and traditions of Botswana.

18. To develop respect for other persons and to live and work cooperatively with others.

19. To learn about conditions conducive to successful family life.

20. To develop good physical health and fitness.

21. To develop psychologically in a manner that is conducive to good mental health.

22. To develop the capacity to appreciate beauty in literature, art, music, and nature.

23. To be able to adapt to social, economic, and technological change by adjusting acquired knowledge to new situations and by taking appropriate actions.

24. To acquire entrepreneurial business skills to participate in national and local development.

\section{Appendix B}

Major Donors of Recent Education Projects in Botswana

United States Agency for International Development (USAID):

Primary Education Improvement Project (1981-91)

Junior Secondary Education Improvement Project (1986-91)

Improving the Efficiency of Education Systems (1986-92)

Operations Experts (occasional contracts: ongoing)

British Overseas Development Agency (ODA) and British Council:

General assistance with variety of long and short-term technical assistance positions to the Ministry of Education (since independence and ongoing)

Botswana Extension College (1973-78) - became part of the Department of Nonformal Education in 1979, with a recent evaluation of the extension work carried out by the International Extension College of the United Kingdom

Teachers as Inservice Tutors Project (1986-onward)

Teachers for Botswana Recruitment Scheme (continuing program under which British teachers are recruited by the British Council but paid by the Botswana government)

Swedish International Development Authority (SIDA) and Agency for Research Cooperation with Developing Countries (SAREC):

Technical assistance and consultants throughout the educational program (ongoing)

Assistance to the University of Botswana (funds, technical assistance to the National Institute of Development Research and Documentation, and joint research projects) 


\section{National Literacy Project (1980-91)}

Teaching Aids Production Unit (1984-onward)

Fund for applied research in the Ministry of Education (continuing)

University of Botswana's Education Research Grants (SAREC research grants for proposals focused on educational development since the 1977 report of the National Commission on Education-headed by T. Husen from the University of Stockholm's International Institute for Education)

Assistance to secondary schools (from time to time)

Capital projects at the Botswana Polytechnic

German Agency for Technical Cooperation (GTZ):

National Literacy Project (initiation and continuing assistance)

Automotive Trades Training School (ongoing)

Assistance to the area of technical education (ongoing)

International Bank for Reconstruction and Development (IBRD) - World Bank (all loan projects have now been completed):

Boipelego Education Project (capital projects-included support for the vast expansion program in junior secondary education)

Brigades (capital projects)

Teacher Training Colleges (capital projects)

Assistance to self-help schools (capital projects)

Unesco/Unicef:

Occasional studies and consultants (ongoing)

Teaching Aids Production Unit (pre-1984)

National Literacy Project

Australian International Development Assistance Bureau (AIDAB):

Education Project for Southern Africa (1986-onward)

\section{Appendix C}

Major External Sources of Support (in Parentheses) for the Creation or Development of Ministerial Organizational Components

Department of Curriculum Development and Evaluation:

Research and Testing Centre (USAID)

Examination Unit (British)

Publications Unit (British)

Curriculum Development Unit (USAID, British, AIDAB)

Teacher Aids Production Unit (Unicef, Swedish)

Educational Broadcasting (British, Swedish)

Department of Nonformal Education:

Literacy (German, Swedish)

Administrative (British, USAID)

Distance Education (British, AIDAB)

Department of Teacher Education (including teacher training colleges):

Preservice (British, USAID, Swedish)

Inservice (British, USAID, Holland, EEC, AIDAB)

Administration (British, USAID)

Department of Primary Education (British, USAID, AIDAB) 
Department of Secondary Education (British, Swedish, USAID, AIDAB)

Planning Unit (British, USAID, Swedish)

Technical Education (British, German, Swedish)

Unified Teaching Service (British TBRS and Volunteers, Peace Corps, German Volunteer Service, Canadian University Service Overseas, Netherlands Volunteers, Australian Overseas Volunteers, UN Volunteers)

Bursaries (British, USAID)

Headquarters, including University of Botswana and Brigades (British and many others with special institutional links with universities in Amsterdam, Ohio, New York, Florida, Manchester, and Edinburgh) 